\title{
EFEKTIVITAS MEDIASI DALAM PENYELESAIAN PERKARA PERCERAIAN DI PENGADILAN AGAMA JAWA TENGAH
}

\author{
Muhammad Saifullah \\ UIN Walisongo Semarang \\ e-mail: say_full2003@yahoo.com
}

\begin{abstract}
Mediation as one of Alternative Dispute Resolution (ADR) is seen as a way dispute resolution humane and just. Humanist because the mechanism decision-making (the peace agreement) become the authority of the parties dispute and maintain good relations. Fair because each party negotiate to option a problem solution from his problem and outputs a win-win solution. Therefore, dispute resolution with litigation is becoming obsolete and people turn to mediation. Through the Supreme Court Regulation (Perma) No. 1 In 2008, mediation has been integrated into the proceedings in the court system. Every civil matters must completed first by way of mediation. Each judge's decision not by way of mediation first, the decision shall be considered null and void. This paper discusses the effectiveness of mediation in the settlement of divorce cases in the Religious Court Central Java, because of a divorce case is a matter of the highest ranks in the Religious Court. The focus of the study is the implementation of divorce mediation cases, mediation success standard divorce cases and the litigants public response to the peace efforts through mediation procedures.
\end{abstract}

Mediasi sebagai salah satu Alternative Dispute Resolution (ADR) dipandang sebagai cara penyelesaian sengketa yang humanis dan berkeadilan. Humanis karena mekanisme pengambilan keputusan (kesepakatan damai) menjadi otoritas para pihak yang bersengketa dan menjaga hubungan baik. Adil karena masing-masing pihak menegosiasikan opsi jalan keluar atas masalahnya dan outputnya win-win solution. Oleh karenanya, penyelesaian sengketa secara litigasi mulai ditinggalkan dan orang beralih ke mediasi. Melalui Peraturan Mahkamah Agung (PerMA) No. 1 Tahun 2008, mediasi telah diintegrasikan dalam sistem beracara di pengadilan. Setiap perkara perdata harus diselesaikan terlebih dahulu melalui cara mediasi. Setiap putusan hakim yang tidak melalui cara mediasi terlebih dahulu, maka putusan dianggap batal demi hukum. Tulisan ini membahas tentang efektivitas mediasi dalam penyelesaian perkara perceraian di Pengadilan Agama wilayah Jawa Tengah, karena perkara perceraian adalah perkara yang menduduki rangking tertinggi di Pengadilan Agama. Adapun fokus kajiannya adalah implementasi mediasi perkara perceraian, standar keberhasilan mediasi perkara perceraian dan respon masyarakat berperkara terhadap upaya damai melalui prosedur mediasi.

Keywords: efektivitas, mediasi, perceraian, damai, Pengadilan Agama. 


\section{Pendahuluan}

Mahkamah Agung telah merubah paradigma mengadili menjadi paradigma menyelesaikan sengketa/perkara hukum. Penyelesaian sengketa perkara perdata melalui litigasi mulai ditinggalkan dan beralih ke Alternative Dispute Resolution/ADR (mediasi). Wujud perubahan ini dilakukan dengan menerbitkan Peraturan Mahkamah Agung (PerMA) No. 2 Tahun 2003, kemudian direvisi melalui PerMA No. 1 Tahun 2008, tentang Prosedur Mediasi di Pengadilan Mahkamah Agung Republik Indonesia. Langkah pemerintah Indonesia ini berkiblat pada negara-negara maju yang telah berhasil menyelesaikan sengketa melalui mediasi, seperti Jepang, Singapura, Amerika Serikat, Canada, Belanda, dan Australia.

Pengadilan sebagai salah satu instrumen penegak hukum telah melaksanakan mediasi sejak 2008. Namun keberhasilan mediasi masih dibawah 4 \%. Hal ini menunjukkan bahwa integrasi mediasi dalam sistem beracara di pengadilan belum efektif. Efektivitas mediasi tidak sepenuhnya tergantung kepada pelaksana penegak hukum (hakim, pengadilan). Menurut Lawrence M. Friedman, bahwa sistem hukum dapat berjalan baik jika tiga elemen sistem hukum saling mendukung, yaitu penegak hukum, aturan hukum dan budaya hukum. Penegak hukum dapat bekerja dengan baik jika aturan hukumnya baik dan jelas, serta masyarakat patuh kepada hukum. Jika ketiga elemen tidak saling mendukung maka penegakkan hukum (law enforcement) menjadi tidak efektif.

Kedudukan Peradilan Agama adalah pelaku kekuasaan kehakiman yang memiliki kompetensi untuk menerima, memeriksa, dan mengadili serta menyelesaikan setiap perkara syari'ah Islam yang diajukan kepadanya. Cakupan kompetensi ini meliputi: perkawinan, waris, wasiat, hibah, wakaf, zakat, infak, shadaqah, dan sengketa ekonomi syari'ah ${ }^{1}$. Dari jenis perkara ini, perkara perkawinan menduduki angka tertinggi dibanding perkara lainnya, khususnya perkara perceraian (marital divorce). Di Pengadilan Agama (khususnya di Jawa), angka perceraian mencapai $80 \%$ - $95 \%$.

1'Lihat Pasal 49UU No. 3 Tahun 2006. 
Berdasarkan data tahun 2011, angka perceraian di Indonesia dari tahun ke tahun jumlahnya cenderung meningkat. Angka perceraian sebelum era reformasi mencapai 60.000 per tahun. Pasca reformasi perceraian rata-rata naik menjadi 200.000 per tahun. Setiap tahun angka pernikahan mencapai 2 juta orang dan 10 \% (200.000) mengalami perceraian. ${ }^{2}$ Ironisnya gugatan perceraian tersebut atas inisiatif dari istri. Hal ini berbeda dengan masa dulu di mana perceraian lebih banyak dilakukan oleh suami melalui gugat talak, kini sebaliknya, inisiasi perceraian justru dari pihak isteri melalui gugat cerai. Berikut data pernikahan dan perceraian di Indonesia:

Tabel 1.

Angka Perceraian di Indonesia ${ }^{3}$

\begin{tabular}{ccccc}
\hline No. & Tahun & Nikah & Cerai & Persen \\
\hline 1 & 2010 & $2,207,364$ & 285,184 & 12.92 \\
2 & 2011 & $2,319,821$ & 258,119 & 11.13 \\
3 & 2012 & $2,291,265$ & 372,577 & 16.26 \\
4 & 2013 & $2,218,130$ & 324,527 & 14.63 \\
\hline \multicolumn{2}{r}{ Jumlah } & $9,036,580$ & $1,240,407$ & 13.73 \\
\hline
\end{tabular}

Demikian juga di Jawa Tengah, perkara perceraian yang didaftarkan di Pengadilan Agama sangat tinggi. Sebagai contoh, Pengadilan Agama Semarang (kelas IA) menerima perkara perceraian dalam jumlah banyak. Tahun 2012 perkara penceraian mencapai 2.817 dari jumlah 3.034 perkara, dan tahun 2013 sebanyak 2.977 dari jumlah 3221perkara. Pengadilan Agama Surakarta sebagai pengadilan kelas 1B, menerima perkara perceraian tahun 2012 sebanyak 851 dari 946 perkara, tahun 2013 sebanyak 853 dari 1.066 perkara. Pengadilan Agama Rembang, menerima perkara perceraian tahun 2012 sebanyak 1.233 dari 1.296 perkara, dan tahun 2013 sebanyak 1.287 dari 1.362 perkara.

\footnotetext{
${ }^{2}$ Perceraian tersebut disebabkan karena beberapa faktor, antara lain persoalan ekonomi, ketidakcocokan, jarak sosial, intelektual, umur, cacat badan kecelakaan, dipenjara, menjadi TKI, dan politik. Baca pada laman http://kuaarjasajr.wordpress.com/2012/06/01/studi-kasus-perceraian-dipengadilan-agama-klungkung/, diakses pada tanggal 4 Januari 2014.

${ }^{3}$ Data Kementerian Agama disampaikan oleh Kasubdit Kepenghuluan. Dimuat di Republika Online 14 September 2014
} 
Data di atas menunjukkan bahwa dari tahun ke tahun, jumlah perkara yang didaftarkan di tiga Pengadilan Agama tersebut semakin meningkat. Fenomena ini juga dialami oleh pengadilan-pengadilan lainnya di Jawa Tengah. Perkara perceraian ini harus diselesaikan melalui cara mediasi sebagai amanat PerMA No. 1 Tahun 2008. Tulisan ini akan mengkaji tentang efektivitas mediasi dalam penyelesaian perkara perceraian di Pengadilan Agama di Jawa Tengah. Kajian ini difokuskan pada implementasi mediasi di Pengadilan Agama Semarang, Surakarta dan Rembang, serta standar ukuran keberhasilan mediasi dan budaya hukum masyarakat berperkara dalam merespon mediasi di Pengadilan Agama tersebut.

\section{Upaya Damai dan Mediasi Peradilan}

Masyarakat Indonesia dikenal sebagai masyarakat yang gemar menyelesaikan masalahnya dengan cara damai. Indikatornya adalah masyarakat selalu menempatkan tokoh agama (toga) dan tokoh masyarakat (tomas) untuk membantu menyelesaikan masalah yang dihadapi oleh masyarakat. Tempat penyelesaian dengan cara damai ini dilakukan di balai pertemuan desa atau di rumah toga atau tomas yang dihadiri oleh orang-orang penting setempat. Sedangkan bagi masyarakat Muslim, penyelesaian masalah dengan cara damai (ișlāḥ) dilakukan di serambi-serambi masjid, yang kemudian dikenal dengan Pengadilan Agama.

Dalam masyarakat adat dikenal beberapa upaya damai dalam penyelesaian sengketa di masyarakat. Bagi masyarakat Aceh, penyelesaian sengketa dengan cara damai dikenal dengan istilah Dong Teungoh yang artinya penengah. Masyarakat Bali menggunakan sangkepan (artinya rapat) untuk penyelesaian sengketa dengan cara damai. Pengertian rapat ini menunjukkan bahwa masalah yang dihadapi atau disengketakan harus dimusyawarahkan. Sengketa ini tidak hanya perkara perdata saja, namun juga perkara pidana (kriminal). Pada masyarakat Batak Karo dikenal penyelesaian sengketa melalui runggun, yang artinya bersidang atau berunding. Masyarakat Karo menganggap bahwa masalah yang muncul di masyarakat merupakan masalah bersama, masalah keluarga, dan masalah kerabat. Jika ada orang yang bermasalah, maka hakikatnya itu menjadi masalah bersama. Pada masyarakat Dayak Taman (Kalimantan Barat), penyelesaian cara damai dikenal dengan istilah "Lembaga 
Musyawarah Kombong". Setiap masalah yang muncul hampir selalu diselesaikan melalui lembaga ini, dan tidak perlu sampai ke pengadilan formal. Jika penyelesaian adat itu telah selesai, maka hasil kesepakatnnya harus diurus berdasarkan adat lingkungan yang bersangkutan.

Dalam sejarah peradaban manusia, konflik pertama kali muncul adalah konflik keluarga dan berhubungan dengan asmara. Anak Nabi Adam AS., Qabil telah membunuh saudara kandungnya atas perjodohan atas dirinya yang tidak sesuai dengan keinginannya. Hingga sekarang, konflik keluarga (perceraian) menjadi konflik yang mendominasi perkara-perkara yang didaftarkan di Pengadilan Agama.

Dalam studi al-Qur'an, konflik rumah tangga terdiri atas nusyuz dan syiqaq. Untuk dua jenis konflik ini, al-Qur'an memberikan teknis penyelesaiannya dengan cara iṣlāḥ (damai). Dalam konflik rumah tangga, penyelesaian sengketa antara suami istri dalam kasus nusyuz harus diselesaikan dengan bertahap dan edukatif. ${ }^{4}$ Demikian juga konflik syiqaq harus diselesaikan dengan cara mengutus hakam (juru damai). ${ }^{5}$

Ajaran damai yang menjadi karakter bangsa Indonesia dan bersumber dari ajaran agama ini menjadi embrio dalam sistem peradilan. Pengadilan sebelum melakukan penyelesaian secara ajudikatif harus selalu mengajak para pihak untuk berdamai. Hal ini berdasarkan: 1) HIR pasal 130 (Pasal 154 RBg, Pasal 31 Rv). ${ }^{6}$ ) UU No. 1/19747, PP No. 9/1975 ${ }^{8}$ UU No. 7/19899 , dan KHI.10 3) SEMA

${ }^{4}$ Tahapan penyelesaian konflik nusyuz ini diatur dalam QS. al-Nisā’ [4] : 34.

5Teknik penyelesaian sengketa ini diatur dalam QS. al-Nisā' [4] : 34. Hākkam adalah juru damai yang berasal dari pihak suami dan istri. Utusan ini dapat dari kalangan keluarga atau kalangan profesional (alkhabirr). Menurut Wahbah al-Zuhaily, bahwa seorang Hākam harus ahli dalam bidangnya dan wajib menjaga kerahasiaan masalah kliennya (khifäzan 'ala asrār al-zaujïyah). Oleh karena itu menurut pandangannya, lebih baik jika Hakam berasal dari keluarga pihak yang bersengketa. Wahbah al-Zuhaily, a-Tafsir al-Munirfial-'Aqidah wa '-Syari'ah wa '-Manhaj (Beirut: Dar al-Fikr, 1991), h.58-59.

6Pada masa Pemerintahan Hindia Belanda melalui Reglement op de burgerlijke Rechtvordering atau disingkat Rv (1894), penyelesaian melalui damai sudah diperkenalkan. Bunyi pasal di atas sebagai berikut: [1] jika pada hari yang ditentukan itu, kedua belah pihak datang, maka pengadilan negeri dengan pertolongan ketua mencoba akan mendamaikan mereka, [2] Jika perdamaian yang demikian itu dapat dicapai, maka pada waktu bersidang, diperbuat sebuah surat (akte) tentang itu, dalam mana kedua belah pihak dihukum akan menepati perjanjian yang diperbuatitu, surat mana akan berkekuatan dan akan dijalankan sebagai putusan yang biasa, [3] Keputusan yang sedemikian itu tidak dapat diijinkan dibanding, [4] Jika pada waktu mencoba akan mendamaikan kedua belah pihak, perlu dipakai seorang juru bahasa, maka peraturan pasal yang berikut dituruti untukitu. 
Muhammad Saifullah

No. 1 Tahun 2002 (Eks Pasal 130 HIR/154 RBg) dan Hasil Diskusi Komisi II Rakernas terbatas MARI. 4) PerMA No. 2 Tahun 2003, kemudian direvisi melalui PerMA No. 1 Tahun 2008 tentang Prosedur Mediasi di Pengadilan MARI. ${ }^{11}$

Melalui PerMA No. 1 Tahun 2008 maka mediasi sudah terintegrasikan dalam sistem peradilan dan disebut mediasi peradilan ${ }^{12}$. Setiap perkara perdata ${ }^{13}$ yang diajukan di pengadilan harus diselesaikan terlebih dahulu melalui mediasi. Mediasi di pengadilan dilakukan oleh mediator hakim maupun mediator non hakim yang telah mengikuti Pendidikan Khusus Profesi Mediator (PKPM) yang diselenggarakan oleh lembaga yang sudah terakreditasi oleh Mahkamah Agung. Dalam melaksanakan tugas dan fungsinya mereka, mereka

\footnotetext{
${ }^{7}$ Pasal 39 UU No. 1 Tahun 1974 menyebutkan bahwa: "Perceraian hanya dapat dilakukan di depan sidang pengadilan setelah pengadilan yang bersangkutan berusaha dan tidak berhasil mendamaikan kedua belah pihak".

${ }^{8}$ Ketentuan pasal 39 diatur lebih lanjut dalam PP No. 9 Tahun 1975 tentang Pelaksanaan UndangUndang Nomor 1 Tahun 1974. Pasal 31-33 sebagai berikut: "Hakim yang memeriksa gugatan perceraian berusaha mendamaikan kedua pihak. Selama perkara belum diputuskan, usaha mendamaikan dapat dilakukan pada setiap sidang pemeriksaan"(Pasal 31), "Apabila tercapai perdamaian, maka tidak dapat diajukan gugatan perceraian baru berdasarkan alasan atau alasan-alasan yang ada sebelum perdamaian dan telah diketahui oleh penggugat pada waktu dicapainya perdamaian" (pasal 32), "Apabila tidak dapat dicapai perdamaian, pemeriksaan gugatan perceraian dilakukan dalam sidang tertutup" (pasal33).

${ }^{9}$ Pasal 65 ini memiliki redaksi yang sama dengan Pasal 39 UU Perkawinan.

10Instruksi Presiden Nomor 1 Tahun 1999 tentang Kompilasi Hukum Islam (selanjutnya ditulis KHI) diatur dalam Pasal 115, 131 (2), 143 (1-2), dan 144 : "Perceraian hanya dapat dilakukan di depan sidang Pengadilan Agama setelah Pengadilan Agama tersebut berusaha dan tidak berhasil mendamaikan kedua belah pihak" (Pasal 115), "Setelah Pengadilan Agama tidak berhasil menasihati kedua belah pihak dan ternyata cukup alasan untuk menjatuhkan talak serta yang bersangkutan tidak mungkin lagi hidup rukun dalam rumah tangga, Pengadilan Agama menjatuhkan keputusannya tentang ijin bagi suami untuk mengikrarkan lagi" (Pasal 131 ayat 2), "Dalam pemeriksaan gugatan perceraian hakim berusaha mendamaikan kedua belah pihak" (Pasal 143 ayat 1), "Selama perkara belum diputuskan, usaha mendamaikan dapat dilakukan pada setiap sidang pemeriksaan" (Pasal 143 ayat 2), "Apabila terjadi perdamaian, maka tidak dapat diajukan gugatan perceraian baru berdasarkan alasan atau alasan yang ada sebelum perdamaian dan telah diketahui oleh penggugat pada waktu dicapainya perdamain" (Pasal 144).

${ }_{11}^{11}$ Tidak menempuh prosedur mediasi berdasarkan peraturan ini merupakan pelanggaran terhadap ketentuan Pasal 130 HIR dan atau Pasal 154 Rbg yang mengakibatkan putusan batal demi hukum.

${ }^{12}$ Dibeberapa Negara, penyebutan Mediasi Peradilan dengan menggunakan beberapa istilah, antara lain: Court-Annexed Mediation, Court-Based Mediation dan Court-Integrated Mediation.

${ }^{13}$ Semua perkara perdata wajib diselesaikan melalui mediasi, kecuali perkara yang diselesaikan melalui prosedur pengadilan niaga, pengadilan hubungan industrial, keberatan atas putusan Badan Penyelesaian Sengketa Konsumen, dan keberatan atas putusan Komisi pengawas Persaingan Usaha (Pasal 4 PerMA No. 1 Tahun 2008).
} 
harus mematuhi ketantuan PerMA No. 1 Tahun 2008 dan Pedomam Perilaku Mediator yang dibuat oleh Mahkamah Agung.

\section{Implementasi Mediasi di Pengadilan Agama Jawa Tengah}

Pengadilan Agama di Jawa Tengah (Semarang, Surakarta dan Rembang) telah melaksanakan amanat Mahkamah Agung dalam penyelesaian perkara perdata melalui mediasi (PerMA No. 1 Tahun 2008). Perkara perceraian yang terdaftar di tiga Pengadilan Agama Jawa Tengah (Semarang, Surakarta dan Rembang) selama empat tahun (2010 s/d 2013) diselesaikan melalui cara mediasi, dan angka keberhasilnnya sangat kecil. Di Pengadilan Agama Semarang hanya 23 perkara dari 10.817 perkara perceraian yang didaftarkan. Di Pengadilan Agama Surakarta keberhasilan mediasi hanya mencapai 2 perkara dari 3.217 perkara perceraian yang didaftarkan. Sedangkan di Pengadilan Agama Rembang, keberhasilan mediasi mencapai 7 perkara dari 4.523 perkara perceraian yang didaftarkan.

Tingkat keberhasilan ini masih jauh dari harapan Mahkamah Agung, yang salah satu tujuan diterbitkannya PerMA mediasi adalah untuk menyelesaikan perkara secara win-win solution dan mengurangi jumlah penumpukan perkara. Berdasarkan hasil penggalian data dan analisis penulis, belum efektifnya mediasi di Pengadilan Agama Jawa Tengah disebabkan beberapa hal sebagai berikut:

\section{Profesionalisme Mediator Hakim}

Proses mediasi di pengadilan dilakukan oleh seorang mediator yang berasal dari unsur hakim dan non hakim. Seseorang yang menjalankan fungsi sebagai mediator harus memiliki sertifikat yang diperoleh setelah mengikuti Pendidikan Khusus Profesi Mediator (PKPM) yang diselenggarakan oleh lembaga yang terakreditasi oleh Mahkamah Agung. Namun jika dalam wilayah pengadilan tidak ada hakim yang bersertifikat, maka hakim di lingkungan pengadilan tersebut dapat menjalankan fungsi sebagai mediator. ${ }^{14}$ Dengan demikian maka bagi hakim yang tidak/belum bersertifikat pun dapat menjalankan fungsi mediator.

\footnotetext{
14LihatPasal 5 ayat 2 PerMA No. 1 Tahun 2008.
} 
Pada teknis pelaksanaannya, hampir semua hakim di Pengadilan Agama bertindak sebagai mediator karena Ketua Pengadilan harus menunjuk dan mencantumkan nama-nama mediator sekurang-kurangnya 5 (lima) mediator. Hal ini dimaksudkan agar semua hakim secara bergantian dapat berfungsi sebagai mediator untuk proses mediasi, disamping melaksanakan tugas utama sebagai hakim untuk proses litigasi. Tujuan lain pencantuman semua hakim ini adalah untuk memudahkan para pihak yang berperkara memilihnya sebagai mediator untuk penyelesaian perkaranya.

Untuk memenuhi kebutuhan pelaksanaan mediasi, Pengadilan Agama Semarang memiliki 30 mediator yang terdiri atas 13 mediator hakim dan 17 mediator non hakim. Dari 13 mediator hakim, 3 diantaranya telah mengikuti Pendidikan Khusus Profesi Mediator (PKPM). Pengadilan Agama Surakarta memiliki 6 mediator hakim dan tidak ada satupun yang bersertifikat mediator. Sedangkan di Pengadilan Agama Rembang dari 7 mediator hakim yang ditunjuk, hanya seorang hakim yang telah memperoleh PKPM.

Jika memperhatikan angka keberhasilan mediasi pada tiga Pengadilan Agama tersebut, keberadaan mediator hakim yang telah atau belum bersertifikat, tidak berpengaruh signifikan terhadap angka keberhasilan mediasi. Hal ini disebabkan karena banyak faktor, antara lain jumlah hakim yang bersertifikat terbatas, faktor sarana ruang mediasi (untuk Pengadilan Agama Semarang), dan penumpukan perkara.

Bagi hakim yang telah bersertifikat, teknik mediasi dilakukan lebih sistematis, terutama dalam menggali interest ${ }^{15}$ dan need ${ }^{16}$ pihak berperkara. Penyelesaian perkara berbasis pada dua hak tersebut, bukan berbasis pada posisi (positions). ${ }^{17}$ Dengan cara ini maka interest dan need akan mudah ditangkap sehingga dapat digeser untuk mencari pilihan-pilihan penyelesaian yang win-win

\footnotetext{
${ }^{15}$ Interest adalah apa yang sebenarnya dikehendaki oleh para pihak dibalik posisi (what we really want)

${ }^{16}$ Need adalah apa yang seharusnya kita miliki (what we must have.)

${ }^{17}$ Positions adalah apa yang kita katakan itulah yang kita inginkan (what we say we want. Posisi juga diartikan suatu keinginan yang telah dipilih secara sadar oleh satu pihak dan yang berlawanan dengan yang dipilih pihak lain. Tidak mungkin dapat dipenuhi, karena dengan memenuhi salah satunya, berarti meniadakan yang lain.
} 
solution. Bagi mediator hakim yang belum bersertifikat, maka mediasi dilakukan berdasarkan ketrampilan yang dimilikinya dan seni mengajak orang untuk berdamai, seperti menanyakan identitas yang bersangkutan dan aktivitas pekerjaanya sehingga dapat memahami lingkungan dan psikologinya. Salah satu hakim di Pengadilan Agama Rembang berpendapat bahwa cara ini efektif untuk membangun kadar komunikasi kepada para pihak yang bersengketa, termasuk pilihan kata yang digunakan. Tentu cara ini tidak salah, namun dari sisi efektivitas dipandang kurang fokus pada upaya menggali faktor-faktor penyebab konflik utama (root causes), bukan pada pemicu konflik (triggers). Sedangkan di Pengadilan Agama Surakarta yang tidak ada satupun hakim yang memiliki sertifikat mediator, maka mediator hakim menekankan pada aspek psikologis dari proses yang ditangkap pada sesi proses mediasi, seperti keinginan kuat untuk bercerai dengan cara penyampaian yang halus sesuai dengan karakter masyarakat Surakarta.

Sertifikat mediator bagi setiap orang yang menjalankan fungsi mediator sangat penting karena berkaitan dengan profesionalisme ${ }^{18}$ dalam proses mediasi. Sertifikat mediator diperoleh setelah seseorang mengikuti pelatihan mediasi minimal 40 (empat puluh) jam lebih. Pelatihan tentang teori dan praktek ini akan membekali hakim memiliki ketrampilan tambahan dalam fasilitasi proses mediasi. Sebagaimana seseorang yang akan menjadi hakim, maka ia harus dibekali materi dalam bidang litigasi. Pendidikan dan pelatihan mediasi kepada calon mediator sangat penting untuk menunjang skill hakim dalam melaksanakan fungsi mediator. Sejak PerMA No. 2 Tahun 2003, Mahkamah Agung bekerjasama dengan IICT dan PMN melaksanakan training mediasi bagi para hakim. Upaya ini perlu dilanjutkan agar para hakim memiliki tambahan skill dalam bidang mediasi.

\footnotetext{
18Profesionalisme menurut Mahkamah Agung RI adalah persyaratan yang diperlukan untuk menjabat suatu pekerjaan (profesi) tertentu yang melaksanakannya memerlukan ilmu pengetahuan, ketrampilan, wawasan dan sikap yang mendukung sehingga pekerjaan profesi tersebut dapat dilaksanakan dengan baik sesuai dengan yang direncanakan. Lihat pidato Ketua Mahkamah Agung RI pada pembukaan Rakernas MARI tahun 1996. Menurut Abdulkadir Muhammad, profesionalisme merupakan pekerjaan yang memiliki 6 (enam) kriteria, yaitu: meliputi bidang tertentu (spesialisasi), berdasarkan keahlian khusus, bersifat tetap, lebih mendahulukan pelayanan daripada imbalan, bertanggungjawab terhadap diri sendiri dan masyarakat, dan berkelompok dalam satu oraganisasi. Prof. Abdulkadir Muhammad, SH., Etika Profesi Hukum, Bandung: PT Citra Aditya Bakti, 2001.
} 
Muhammad Saifullah

\section{Pemberdayaan Mediator non Hakim}

Daftar nama-nama mediator Pengadilan Agama Surakarta dan Rembang mayoritas terdiri atas mediator dari unsur hakim (atau disebut mediator hakim). Hal ini disebabkan karena tidak ada mediator dari unsur masyarakat (luar pengadilan) yang telah memperoleh pendidikan dan pelatihan mediasi yang mendaftarkan diri pada pengadilan tersebut sebagai mediator unsur non hakim (atau disebut mediator non hakim). Hal ini berbeda dengan Pengadilan Agama Semarang yang memiliki mediator non hakim sebanyak 17 mediator. Namun realitasnya mereka tidak dipilih oleh para pihak yang berperkara karena pemilihan terhadapnya diharuskan membayar jasa mediator berdasarkan kesepakatan antara mediator dengan pihak yang berperkara. Oleh karenanya, pihak berperkara lebih cenderung memilih mediator hakim karena tidak ada beban tambahan (gratis).

Disamping alasan diatas, Pengadilan Agama Semarang kurang memanfaatkan mediator non hakim. Jika Pengadilan Agama dapat memanfaatkan mediator non hakim, seperti yang dilakukan oleh Pengadilan Agama Jakarta, Denpasar Bali, dan beberapa Pengadilan Agama di Jawa Timur, maka akan meringankan beban Pengadilan Agama Semarang. Pada pengadilan tersebut, setelah sidang pertama selesai, proses mediasi dilakukan oleh mediator non hakim yang menempati kantor mediator dan selanjutnya mediasi dilakukan di ruang mediasi. Biaya mediasi berkisar antara Rp. 60.000 - Rp. 100.000/ perkara. Biaya ini dibebankan kepada para pihak yang berperkara. Penetapan biaya ini untuk menghindari adanya persepsi masyarakat bahwa mediator seperti advokat sehingga pihak yang berperkara takut jika memilih mediator non hakim, karena akan dikenakan biaya tinggi, seperti honor untuk membayar advokat.

Keuntungan lain bagi pengadilan adalah para hakim tidak terbebani oleh tugasnya sebagai mediator. Berdasarkan pengakuan beberapa hakim di tiga Pengadilan Agama Jawa Tengah, mediasi merupakan tugas tambahan bagi hakim dan justru dapat mengakibatkan bertambahnya penumpukan perkara. Oleh karenanya proses mediasi dilakukan dalam waktu yang singkat, dan terkesan sebagai formalitas untuk memenuhi ketentuan pasal 2 PerMA No. 1 Tahun 2008. Disamping itu janji Mahkamah Agung, pasal 25 yang mengatur 
tentang kriteria keberhasilan mediasi dan insentif bagi hakim yang berhasil menjalankan fungsi mediator, belum terpenuhi hingga sekarang.

Untuk meningkatkan efektivitas mediasi di Pengadilan Agama, pengadilan dapat melakukan kerjasama dengan Perguruan Tinggi atau lembaga-lembaga mediasi yang memiliki mediator. Hal ini sangat strategis bagi pelaksanaan mediasi di pengadilan dan bagi Perguruan Tinggi Agama Islam (PTAI), khsususnya Fakultas Syari'ah. Pendidikan Khusus Profesi Mediator (PKPM) sudah mulai dikembangkan di beberapa Perguruan Tinggi sehingga Perguruan Tinggi dan Pengadilan perlu melakukan kerjasama. Maka jika kerjasama ini dapat terjalin dan terlaksana akan menjadi peluang pekerjaan bagi alumni-alumni Fakultas Syari'ah yang bersertifikat sebagai mediator. Dengan cara ini maka pelaksanaan mediasi perkara perceraian di pengadilan dapat berjalan dengan baik, dilakukan oleh kalangan profesional dan tidak menjadi beban bagi hakim yang memiliki tugas pokok memutus perkara.

\section{Fasilitasi Sarana Mediasi}

Mediasi di Pengadilan Agama Surakarta dan Rembang dilakukan di ruang khusus yang digunakan untuk proses mediasi. Sedangkan di Pengadilan Agama Semarang, mediasi dilakukan di ruang hakim (yang sebelumnya dilakukan di ruang khusus mediasi). Jika memperhatikan angka keberhasilan mediasi, maka faktor ruang bukan sebagai penentu keberhasilan mediasi. Keberhasilan mediasi sangat ditentukan oleh banyak faktor, antara lain kemauan para pihak untuk menyelesaikan masalahnya dengan cara damai, kemampuan mediator, ruang mediasi, aturan, dan keterlibatan advokat.

Ruang mediasi di Pengadilan Agama pada umumnya sempit dan kurang memadai untuk proses mediasi. Pada Pengadilan Agama Surakarta dan Rembang, ruang mediasi sangat sempit sehingga pihak yang berperkara kurang nyaman. Sedangkan mediasi di Pengadilan Agama Semarang dilakukan di ruang kantor hakim, sehingga proses mediasi kurang sejalan dengan ketentuan mediasi, dimana pelaksanaan mediasi dilakukan secara tertutup dan rahasia. Ruang yang terbuka untuk umum akan mengganggu proses mediasi dan tidak menjaga kerahasiaan materi mediasi. Menurut Soerjono Soekanto, tanpa adanya 
sarana/fasilitas yang memadai, maka mustahil penegakan hukum (melalui mediasi) akan efektif.19

\section{Standar Ukuran keberhasilan Mediasi dalam Perkara Perceraian}

Standar keberhasilan mediasi perkara perceraian diukur dari tidak jadinya pereceraian antara suami dengan istri yang diwujudkan dengan pencabutan gugatan oleh penggugat. Ketentuan ini sangat sulit untuk dipenuhi dalam penyelesaian perkara melalui mediasi. Penyelesaian perkara perceraian yang dilakukan dengan cara damai dan hasil kesepakatannya adalah bercerai (karena dipandang lebih maslahah), dianggap bertentangan dengan beberapa pengertian rukun dan damai dalam perkara perceraian.

Memperhatikan beberapa peraturan (UU Perkawinan, Kompilasi Hukum Islam/KHI, dan Pedoman Pelaksanaan Tugas dan Administrasi Peradilan Agama), tidak mengenal kesepakatan damai antara suami dan istri untuk bercerai. UndangUndang Perkawinan No. 1 Tahun 1974 pasal 39 menyebutkan: (1) Perceraian hanya dapat dilakukan di depan sidang pengadilan setelah pengadilan yang bersangkutan berusaha dan tidak berhasil mendamaikan kedua belah pihak, (2) Untuk melakukan perceraian harus ada cukup alasan, bahwa antara suami-istri itu tidak akan dapat hidup rukun sebagai suami istri. Berdasarkan pasal ini, maka perceraian dianggap bukan kerukunan (perdamaian). Perdamaian terjadi jika pasangan suami istri tersebut kembali utuh (tidak berpisah).

Ukuran keberhasilan mediasi seperti ini kurang sejalan dengan prinsipprinsip yang dikembangkan dalam ilmu mediasi. Kesepakatan antara suami dan istri untuk berdamai dengan cara berpisah (cerai) dapat menjadi jalan terbaik bagi keduanya. Solusi damai dengan cara bercerai dapat menjaga hubungan antara keluarga dan anak-anak, serta proses perceraian dapat dilakukan dengan cepat, mudah dan biaya ringan.

Standar keberhasilan mediasi perkara perceraian dengan dicabutnya gugatan perceraian merupakan sesuatu yang sulit untuk dicapai. Pernikahan merupa-

\footnotetext{
${ }^{19}$ Soerjono Soekanto, Faktor-faktor yang Mempengaruhi Penegakan Hukum, Jakarta: Rajawali, 2013, h. 37.

192 || Volume 25, Nomor 2, Oktober 2015

AL-AHKAM — ISSN 0854-4603
} 
kan perkara yang berkaitan dengan hati dan perasaan, demikian juga masalah perceraian. Tingkat kesulitan mediasi kasus perceraian disebabkan karena kekerasan fisik (kekerasan Dalam Rumah Tangga/KDRT), perselingkuhan, ekonomi yang berdampak pada sakit hati. Konflik rumah tangga yang terkait dengan sakit hati ini umumnya sulit diselesaikan karena ibarat orang sedang sakit, ia sedang sakarat al-maut (puncak kematian). Pada umumnya, hampir semua penggugat yang mengajukan gugatannya ke pengadilan merupakan klimak dari upaya damai yang gagal. Jadi kalau dimediasi dalam pengertian rukun kembali (perkawinan menjadi utuh) tentu sulit untuk dilakukan, karena pada umumnya mereka ngotot (bersikukuh) untuk bercerai. Sehingga perkara perceraian yang didaftarkan di pengadilan pada akhirnya diselesaikan melalui cara litigasi. Hal ini berbeda dengan sengketa harta (seperti warisan dan harta bersama) yang mudah untuk diselesaikan secara damai.

Menurut Jasiruddin (mantan Ketua Pengadilan Agama Semarang) dan Wahyudi (hakim Pengadilan Agama Semarang) keberhasilan mediasi harus diukur dari kesepakatan damai yang disepakati oleh penggugat dan tergugat, meskipun kesepakatannya untuk bercerai. Senada dengan pendapat ini adalah Ketua Pengadilan Agama Rembang (H. Ilham Suhrowardi). Jasirudin menegaskan bahwa orang yang melakukan gugatan cerai pada umumnya masalahnya sudah kompleks, ibarat orang sakit sudah tahap kronis. Jadi kalau didamaikan dalam pengertian tidak jadi cerai, sulit untuk dicapai. Mereka yang mendaftarkan kasusnya ke pengadilan memiliki tujuan untuk bercerai, bukan untuk meminta nasihat rukun kembali. Bagi Ilham, kesepakatan cerai antara suami dan istri dan perceraian ini dipandang lebih maslahah bagi pihak yang berperkara, maka keputusan damai dengan cara bercerai harus diakui sebagai bentuk keberhasilan mediasi. ${ }^{20}$

Konsep talak dalam agama Islam adalah sesuatu yang halal namun dibenci Allah. Perceraian diperbolehkan agama karena dipandang sebagai solusi penyelesaian konflik yang baik, dan akan menghentikan konflik yang lebih

\footnotetext{
${ }^{20}$ Rangkuman hasil wawancara dengan para hakim di Pengadilan Agama Semarang dan Rembang.
} 
dalam dan berkepanjangan. Sehingga perceraian tidak dipandang sebagai kerusakan (mafsadah), namun dipandang sebagai kemaslahatan (bagi para pihak). Jika cerai lebih baik (maslahah), maka cerai harus ditempuh agar tidak terjerumus pada kerusakan, seperti percekcokan yang terus-menerus dan munculnya tindak kekerasan, serta mengganggu psikologis anak-anaknya.

Berdasarkan analisis di atas, maka standar ukuran keberhasilan perkara perceraian dengan gagalnya bercerai perlu dirubah. Jika standar ini tidak direvisi, maka Pengadilan Agama tidak akan mampu melaksanakan amanat PerMA No. 1 Tahun 2008 dimana melalui mediasi diharapkan dapat mengurangi penumpukan perkara. Pada sisi lain, jenis perkara tertinggi di pengadilan adalah perkara perceraian dan jumlahnya selalu naik dari tahun ke tahun, sehingga pada akhirnya Pengadilan Agama akan dituduh sebagai lembaga peradilan yang tidak mampu melaksanakan mediasi dengan baik.

Fakta lain juga menunjukkan bahwa beberapa gugatan yang dicabut sebagai hasil kesepakatan damai dalam proses mediasi, pada bulan-bulan berikutnya didaftarkan lagi sebagai gugatan. Hal ini disebabkan karena hasil kesepakatan mediasi tidak dapat dilaksanakan (workable), dan sebagian lain kesepaktan damai dilakukan tidak sepenuhnya, atau meminjam istilah Johan Galtung, kesepakatan damai hanya pada level negative peace, ${ }^{21}$ bukan positive peace. ${ }^{22}$

\section{Budaya Hukum Masyarakat Berperkara di Pengadilan Agama Jawa Tengah}

Efekvitas hukum berasal dari masyarakat, dan bertujuan untuk mencapai kedamaian dalam masyarakat. ${ }^{23}$ Oleh karenanya dipandang dari sudut tertentu, maka masyarakat dapat mempengaruhi pelaksanaan mediasi di pengadilan. Keberhasilan mediasi peradilan tidak cukup hanya didukung oleh aturan-aturan tentang mediasi dan pelaksana mediasi yang profesional,

\footnotetext{
${ }^{21}$ Negative Peace: the absence of violence, absence of war.

${ }^{22}$ Positive peace: the integration of human society.

23Soerjono Soekanto, Faktor-faktor yang Mempengaruhi Penegakan Hukum, Jakarta: Rajawali, 2013, h. 45
}

194 || Volume 25, Nomor 2, Oktober 2015

AL-AHKAM — ISSN 0854-4603 
namun juga membutuhkan kesadaran masyarakat tentang makna perdamaian dalam kehidupan, atau meminjam istilah Lawrence M. Friedman disebut budaya hukum. Budaya hukum adalah kesadaran masyarakat tentang kepatuhan terhadap aturan-aturan hukum yang dibangun atas pondasi pemahaman terhadap pentingnya perdamaian.

Soekanto menjelaskan bahwa budaya hukum yang mendukung efektivitas penegakan hukum tergantung pada faktor masyarakat dan faktor kebudayaan. Faktor masyarakat adalah persepsi masyarakat terhadap hukum, sehingga hukum dipandang sebagai norma, pengetahuan dan tata hukum. Sedangkan faktor kebudayaan adalah sistem yang mencakup nilai-nilai yang mendasari hukum yang berlaku, nilai-nilai yang dianggap baik (sehingga dianuti), dan nilai-nilai yang dianggap buruk (sehingga dihindari). Mediasi sebagai produk hukum yang harus diterapkan dalam sistem penyelesaian sengketa di peradilan harus dilaksanakan. Pasal 2 ayat 3 PerMA No. 1 Tahun 2008 menegaskan bahwa: "Tidak menempuh prosedur mediasi berdasarkan peraturan ini merupakan pelanggaran terhadap ketentuan Pasal 130 HIR dan atau Pasal 154 Rbg yang mengakibatkan putusan batal demi hukum". Atas "paksaan" pasal ini maka penegak hukum dan masyarakat harus melaksanakannya. Masyarakat sebagai salah satu pendukung berjalannya sistem hukum mediasi di pengadilan bersikap enggan untuk melakukan mediasi. Berdasarkan hasil interview dan observasi peneliti, keengganan masyarakat penggugat perkara perceraian disebabkan karena kurangnya pemahaman terhadap mediasi dan rendahnya budaya masyarakat untuk berdamai.

\section{Kurangnya Pemahaman tentang Mediasi Pengadilan sebagai Kewajiban}

Term mediasi merupakan istilah yang kurang populer bagi masyarakat Indonesia. Istilah ini mulai dikenal setelah Mahkamah Agung menerbitkan PerMA no. 2 Tahun 2003 tentang Prosedur Mediasi di Pengadilah Mahkamah Agung Republik Indonesia. Selanjutya tahun 2008 melalui PerMA No. 1 Tahun 2008, mediasi lebih dikenal dalam masyarakat hukum karena mediasi wajib ditempuh dalam penyelesaian perkara perdata. Meskipun istilah ini sudah 
dikenal namun pemahaman masyarakat tentang mediasi masih terbatas. Masyarakat (penggugat) perceraian di pengadilan Agama Jawa Tengah memiliki persepsi tentang mediasi sebagai berikut:

Pertama, masyarakat menganggap bahwa perkara yang sudah didaftarkan di pengadilan tidak perlu dilakukan mediasi karena mediasi (upaya damai) sudah dilakukan sebelum perkara didaftarkan. Sikap ini muncul pada saat sidang pertama untuk penunjukan mediator. Hakim pada sidang pertama menjelaskan tentang pengertian mediasi dan tujuannya. Bagi para penggugat, keharusan mediasi sering ditolak pada sidang pertama. Tawaran ini ditolak dengan alasan tidak perlu ada mediasi (perdamaian), karena para pihak sudah melakukan mediasi sebelum perkaranya diajukan ke pengadilan.

Persepsi masyarakat di tiga wilayah Pengadilan Agama Jawa Tengah menganggap bahwa mediasi tidak perlu dilakukan. Mereka tidak mengetahui bahwa mediasi wajib di tempuh. Ketidaktahuan terhadap pasal 2 ayat 3 PerMA No. 1 Tahun 2008 bahwa: "Tidak menempuh prosedur mediasi berdasarkan peraturan ini merupakan pelanggaran terhadap ketentuan Pasal 130 HIR dan atau Pasal 154 Rbg yang mengakibatkan putusan batal demi hukum", menyebabkan mediasi ditolak oleh penggugat. Setelah hakim menjelaskan bahwa mediasi suatu prosedur yang wajib ditempuh, para pihak dapat menerimanya.

Penjelasan hakim pada sidang pertama tentang mediasi, merubah persepsi masyarakat sehingga mereka yang menganggap mediasi tidak perlu berubah menjadi mediasi harus dilakukan, meskipun mereka tidak menghendakinya. Menurut beberapa hakim, bahwa perubahan persepsi ini berdampak positif pada proses pelaksanaan mediasi. Semula pada sidang pertama, masyarakat terkesan menolak mediasi, pada sesi proses mediasi mereka lebih lunak dan mengikuti proses mediasi dengan baik.

Kedua, masyarakat menganggap bahwa mediator sama dengan advokat, sehingga penyelesaian melalui mediasi membutuhkan honor mahal seperti honor advokat. Persepsi ini dibangun oleh mesyarakat karena di pengadilan hanya ada hakim, pengacara (advokat) dan pegawai administrasi. Kebanyakan 
mereka tidak mengenal profesi mediator. Mereka mengetahui profesi mediator ketika ada penjelasan pada sidang pertama.

Untuk masyarakat di wilayah Pengadilan Agama Surakarta dan Rembang, hakim tidak menyampaikan informasi tentang mediator non hakim karena tidak ada satupun mediator dari unsur non hakim. Oleh karenanya mereka di suruh untuk memilih, dan akhirnya hakimlah yang menunjuk mediator (hakim). Sedangkan di Pengadilan Agama Semarang, para pihak diberi kesempatan untuk memilih mediator yang dikehendakinya. Daftar nama-nama mediator ini dipasang pada ruang sidang dan ruang tunggu. Akibat adanya persepsi penyamaan mediator dengan advokat, maka mereka lebih memilih mediator (hakim).

Persepsi penyamaan mediator dengan advokat juga berdampak pada keinginan kuat untuk menggunakan mediator (hakim). Agar mereka tidak membayar atas jasa penggunaan mediator, maka ia memilih mediator hakim. Pasal 10 PerMA mediasi menyebutkan bahwa penggunaan jasa mediator hakim tidak dipungut biaya. Tanpa mempertimbangkan aspek-aspek lain, maka kebiasaan atau yang sudah menjadi tradisi di pengadilan adalah "lebih baik" memilih mediator hakim. Sebagian advokat juga menyarakan agar memilih mediator hakim supaya kliennya tidak dikenakan biaya jasa mediator. Persepsi masyarakat tersebut harus diluruskan agar dapat memahami mediasi dengan benar.

Untuk merubah persepsi masyarakat terhadap mediasi dan agar mediasi efektif maka harus dilakukan penjelasan tentang mediasi terhadap masyarakat (pihak yang berperkara). Menurut Soerjono Soekanto, perubahan persepsi ini dapat dilakukan melalui persuasion, yakni persuasi terhadap masyarakat agar mereka mengetahui hukum mediasi, ${ }^{24}$ dan pervasion, yaitu penerangan dan penyuluhan kepada masyarakat tentang hukum mediasi.

\footnotetext{
${ }^{24}$ Persuasi ini bisa dilakukan pada awal proses mediasi dengan cara menjelaskan maksud dan tujuan mediasi, kelebihan mediasi atas litigasi, proses mediasi, tugas mediator, dan hal-hal yang tidak diperbolehkan dalam proses mediasi.
} 
Muhammad Saifullah

\section{Rendahnya Budaya Masyarakat untuk Berdamai}

Disamping persepsi masyarakat terhadap mediasi sebagaimana dijelaskan diatas, faktor prilaku masyarakat yang rendah terhadap upaya damai menyebabkan pelaksanaan mediasi di pengadilan kurang efektif. Persepsi masyarakat (penggugat) terhadap mediasi (upaya damai) berpengaruh terhadap prilakunya. Prilaku masyarakat yang kurang mendukung terhadap sistem hukum menyebabkan hukum kurang berjalan efektif. Agar mediasi dapat berjalan dengan baik, maka pelaksana mediasi (hakim dan pengadilan), aturan tentang mediasi dan masyarakat harus saling medukung.

Rendahnya budaya masyarakat untuk berdamai ini bersumber dari faktor dirinya dan faktor (pengaruh) dari luar. Faktor pertama, sikap masyarakat yang bersumber dari dirinya adalah adanya persepsi masyarakat terhadap mediasi yang diwujudkan dalam bentuk prilaku, sehingga mereka menolak melakukan mediasi. Sedangkan faktor luar adalah pengaruh dari pihak lain (perangkat desa) yang mempengaruhi penggugat dan atau tergugat untuk tidak melakukan mediasi.

Dalam perkara perceraian, masyarakat (pihak yang berperkara) merespon mediasi dengan cara yang berbeda-beda. Bagi masyarakat Surakarta, penolakan mediasi dilakukan dengan cara halus, seperti ungkapan: "kulo sampun mboten kiyat urip sesarengan malih pak hakim" (saya sudah tidak kuat hidup berdampingan lagi pak hakim). Penggunaan bahasa Jawa kadang digunakan dalam proses mediasi, sehingga suasana mediasi menjadi hangat tidak mencerminkan orang yang sedang bertengkar. Meskipun para pihak (penggugat dan tergugat) sedang berperkara, para pihak tanpak melakukan komunikasi dengan baik. Hal ini juga didukung oleh ruang tunggu yang berada dalam gedung dan sempit sehingga para pihak duduk berdekatan. Situasi ini berbeda dengan suasana yang terjadi di Pengadilan Agama Semarang dan Rembang dimana ruang tunggu berada di ruang yang terbuka, sehingga antara pihak penggugat dan tergugat sering berjauhan.

Respon masyarakat terhadap mediasi di Pengadilan Agama Semarang dilakukan secara tegas. Penolakan terhadap mediasi dilakukan dengan alasan 
bahwa kehadiranya di pengadilan untuk bercerai, bukan untuk berdamai. Sedangkan di Pengadilan Rembang, penolakan mediasi dilakukan secara vulgar, bahkan penyampainnya dengan suara tinggi. Ungkapan seperti: "pokoknya saya nggak mau, saya ingin cerai" mencerminkan bahwa tidak ada ruang mediasi untuk penyelesaian perkara perceraian atas dirinya. ${ }^{25}$

Sikap masyarakat ini dipengaruhi oleh budaya setempat. Bagi masyarakat pesisir (Rembang) yang mayoritas adalah masyarakat nelayan, respon terhadap upaya damai dipengaruhi oleh tata kehidupannya. Menurut Arief Nooryadi (yang pernah bertugas di Pengadilan Agama Blora dan Pengadilan Agama Wonogiri), prilaku masyarakat dalam menyelesaikan perkara perceraian berbeda-beda sesuai dengan karakter masyarakat setempat. Masyarakat Wonogiri lebih mudah dan santun dalam merespon mediasi, demikian juga masyarakat (Samin) Blora, meskipun faktor komunikasi menjadi kendala. Sehingga penyelesaian perkara melalui mediasi di Pengadilan Agama Rembang harus ada treatment khusus.

Karakter masyarakat pesisir dalam penyelesaian perkara perceraian di Pengadilan Agama Rembang membutuhkan kerja keras mediator (hakim) untuk memberikan percerahan tentang pentingnya upaya damai melalui mediasi. Meskipun demikian kadang, sikap-sikap kekerasan muncul dalam sidang pengadilan dan proses mediasi. Seorang tergugat (suami) misalnya, melakukan pelucutan perhiasan di area pengadilan terhadap penggugat (istri) atas perhiasan yang dipakainya. Pelepasan perhiasan ini disebabkan karena tergugat merasa kecewa atas sikap istrinya yang lebih percaya kepada saudara-saudaranya, daripada kepada dirinya. ${ }^{26}$

Sedangkan faktor (kedua) rendahnya budaya damai yang berasal dari luar adalah adanya pengaruh dari pihak lain (pamong desa, atau sejenisnya). Faktor eksternal ini sangat kuat, yang dapat mempengaruhi keberhasilan mediasi. Mediasi yang dilakukan setelah sidang pertama harus dihadiri oleh

\footnotetext{
25Rangkuman hasil wawancara dengan para hakim di Pengadilan Agama Rembang.

26Rangkuman hasil wawancara dengan pihak-pihak yang berperkara di Pengadilan Agama Rembang.
} 
para pihak yang berperkara (penggugat dan tergugat). Tanpa kehadiran pihak tergugat mediasi tidak dapat dilakukan.

Masyarakat memiliki kesadaran bahwa proses perceraian di pengadilan membutuhkan waktu yang lama dan biaya banyak. Penyelesaian perkara perceraian lebih cepat jika pihak tergugat tidak datang di pengadilan. Ketidakhadiran tergugat pada sidang pengadilan kadang dilakukan dengan sengaja, yakni adanya anjuran dari pamong desa agar tergugat tidak hadir dalam sidang supaya proses perceraiannya lebih cepat (putusan verstek). Bahkan kadang kesepakatan agar tergugat tidak hadir dalam sidang pengadilan merupakan hasil kesepakatan antara penggugat dan tergugat. Hal ini dilakukan karena pihak tergugat menerima atas ajakan untuk cerai dan biasanya sudah ada kesepakatan terkait dengan pembagian harta gono-gini dan hak pemeliharaan terhadap anak. ${ }^{27}$

Meskipun pihak tergugat tidak hadir dalam sidang pertama, hakim tidak langsung melakukan putusan verstek. Jika hakim memiliki persepsi bahwa gugatan yang diajukan ada ruang untuk mediasi maka pengadilan akan memanggil ulang pihak tergugat. Jika tergugat tetap tidak hadir maka hakim akan melakukan putusan verstek. Namun hal ini sangat jarang dilakukan karena pemanggilan ulang akan memperpanjang waktu penyelesaian perkara, sehingga ketidakhadiran pihak tergugat di pengadilan menyebabkan mediasi tidak bisa dilaksanakan (gagal).

Faktor internal dan eksternal diatas, menyebabkan mediasi sulit untuk ditempuh karena sebagian besar pihak yang berperkara (penggugat) enggan untuk melakukan mediasi. Langkah penggugat mengajukan gugatannya ke pengadilan adalah langkah final, sehingga mereka menginginkan perceraian bukan sebaliknya. Sikap sakit hati atau luka yang dalam, sulit untuk diobati dengan cara damai. Hal ini berakibat cara-cara yang dilakukan oleh mediator dalam proses mediasi tidak akan mengubur keinginan kuatnya untuk bercerai.

\footnotetext{
${ }^{27}$ Kesimpulan ini merupakan hasil wawancara dengan penggugat, keluarga penggugat, dan beberapa hakim di Pengadilan Agama Semarang, Surakarta dan Rembang.
} 
Sikap masyarakat yang sulit memberikan maaf atau cara penyelesaian sengketa dipengaruhi oleh budayanya. Oleh karenanya untuk membangun budaya damai (peace building), perlu dilakukan dua cara, yaitu mengajarkan dan membudayakan hidup damai melalui ajaran-ajaran agama, dan melestarikan dan mengamalkan tradisi lokal.

Ajaran agama Islam menerangkan agar manusia memberikan maaf sebelum orang lain meminta maaf. Penyelesaian konflik rumah tangga (syiqaq dan nusyuz) telah diajarkan Allah melalui tahapan-tahapan penyelesaian konflik seperti yang dimuat dalam surat al Nisa' ayat 34-35. Ajaran damai juga dapat digali dari tradisi-tradisi lokal bangsa Indonesia. Oleh karena masyarakat harus mengamalkan ajaran agamanya dalam penyelesaian sengketa dengan cara damai dan menggunakan local wisdom yang menjadi warisan leluhur bangsa Indonesia.

Cara kedua, masyarakat harus belajar dari budaya lokal yang mengedepankan cara damai dalam menyelesaikan sengketa. Masyarakat Indonesia merupakan masyarakat yang cenderung menyelesaikan masalahnya melalui hukum adat atau tradisi yang turun temurun. Hukum adat sebagai suatu sistem hukum memiliki pola sendiri dalam menyelesaikan sengketa. Hukum adat memiliki karakter yang khas dan unik bila dibandingkan dengan sistem hukum lain. Ia lahir dan tumbuh dari masyarakat, sehingga keberadaannya bersenyawa dan tidak dapat dipisahkan dari masyarakat. ${ }^{28}$ Hukum adat merupakan wujud yuris fenomenologis dari masyarakat adat. Adat masyarakat untuk menyelesaikan masalahnya sangat variatif berdasarkan daerah masing-masing. Setiap daerah memiliki kearifan lokal ${ }^{29}$ dalam merespon masalah yang dihadapinya. Kearifan lokal dalam membangun budaya damai memiliki kontribusi besar bagi upaya penyelesaian sengketa di

\footnotetext{
${ }^{28}$ Syahrizal Abbas, Mediasi dalam Perspektif Hukum Syari'ah, Hukum Adat, dan Hukum Nasional (Jakarta: Kencana Prenada Media Group, 2009), h. 235

${ }^{29}$ Kearifan lokal adalah semua bentuk pengetahuan, keyakinan, pemahaman atau wawasan serta adat kebiasaan atau etika yang menuntun perilaku manusia dalam kehidupan di dalam komunitas ekologis. Semua bentuk kearifan lokal ini dihayati, dipraktekkan, diajarkan dan diwariskan dari generasi ke generasi sekaligus membentuk pola perilaku manusia terhadap sesama manusia.
} 
Indonesia. Upaya ini sejalan dengan PerMA No. 1 Tahun 2008 yang mengharuskan setiap sengketa perdata harus diselesaikan dengan cara mediasi.

\section{Kesimpuan}

Mediasi perkara perceraian di Pengadilan Agama Jawa Tengah belum efektif karena belum sesuai dengan maksud diterbitkannya Peraturan Mahkamah Agung tentang Prosedur Mediasi di pengadilan. Belum efektifnya mediasi ini disebabkan karena pelaksana mediasi belum sepenuhnya (secara maksimal) melakukan mediasi dan masih terkesan hanya memenuhi formalitas, standar ukuran keberhasilan mediasi perkara perceraian yang sulit dicapai, dan budaya masyarakat dalam merespon upaya damai di pengadilan. Agar mediasi dapat efektif maka perbaikan dan perubahan yang meliputi pelaksana mediasi, aturannya dan budaya masyarakat harus dilakukan dan berjalan seiring dan saling mendukung.[a]

\section{DAFTAR PUSTAKA}

Abbas, Syahrizal, Mediasi dalam Perspektif Hukum Syari'ah, Hukum Adat, dan Hukum Nasional, Jakarta: Kencana Prenada Media Group, 2009.

al-Zuhaily, Wahbal, al-Tafsir al-Munir fi al-aqidah wa al-Syari'ah wa al-Manhaj, Beirut: Dar al-Fikr, 1991.

Friedman, Lawrence M., American Law, New York: W.W. Norton and Company, 1984.

Mahkamah Agung, Naskah Akademis Mengenai: Court Dispute Resolution, Jakarta: Puslitbang Hukum dan Peradilan Badan Litbang Diklat Kumdil MARI, 2003.

Mahkamah Agung, Naskah Akademis Mediasi, Jakarta: Puslitbang Hukum dan Peradilan Badan Litbang Diklat Kumdil MARI, 2007.

Mahkamah Agung, Buku Tanya Jawab Peraturan Mahkamah Agung No. 1 Tahun 2008 tentang Pelaksanaan Mediasi di Pengadilan, Jakarta; MARI, JICA, IICT, 2008. 
Mahkamah Agung, Mediasi dan Perdamaian, Jakarta: Proyek Pendidikan dan Pelatihan Teknis Fungsional Hakim dan Non Hakim, 2003.

Mahkamah Agung, JICA, IICT, Buku Komentar Peraturan Mahkamah Agung No. 1 Tahun 2008 tentang Pelaksanaan mediasi di Pengadilan, Jakarta; MARI, JICA, IICT, 2008.

Muhammad, Abdulkadir, Etika Profesi Hukum, Bandung: Citra Aditya Bakti, 2001.

Soekanto, Soerjono, Faktor-faktor yang Mempengaruhi Penegakan Hukum, Jakarta: Rajawali, 2013.

Sukadana, I Made, "Mediasi dalam Sistem Peradilan Indonesia untuk Mewujudkan Proses Peradilan Yang Cepat dan Biaya Ringan", Disertasi Universitas Brawijaya, 2006.

Suzanne dan Reese, Melanie, Mediation Theory and Practice, Boston, New York etc.: Perason Education Inc., 2005,

Syukur, Fatahillah A, Mediasi Yudisial di Indonesia Peluang dan Tantangan dalam Memajukan Sistem Peradilan, Bandung; Mandar Maju., 2012.

Usman, Rachmadi, Mediasi di Pengadialan dalam Teori dan Praktek, Jakarta: Sinar Grafika, 2012.

Witanto, D.Y., Hukum Acara Mediasi, Bandung: Alfabeta, 2011.

\section{Peraturan dan Undang-undang:}

Instruksi Presiden Nomor 1 Tahun 1999 tentang Kompilasi Hukum Islam di Indonesia.

Perma No. 1 Tahun 2008 tentang Prosedur Mediassi di Pengadilan MARI.

PP No. 9 Tahun 1975 tentang Pelaksanaan Undang-undang Nomor 1 Tahun 1974.

Undang-undang No. 30 Tahun 1999 tentang Arbitrase dan Alternatif Penyelesaian Sengketa.

UU No. 1 Tahun 1974 tentang Perkawinan.

UU No. 3 Tahun 2006 tentang Peradilan Agama . 
Muhammad Saifullah

\section{Wawancara:}

Rangkaman wawancara dengan Hakim Agung dan Pokja Mediasi di Mahkamah Agung.

Rangkuman hasil wawancara dengan para hakim di Pengadilan Agama Semarang dan Rembang. 